\title{
The volume of uterine fluid in 'implanting' and 'delayed implanting' mice
}

\author{
R. C. Hoversland and H. M. Weitlauf \\ Department of Anatomy, School of Medicine, University of Oregon Health Sciences Center, \\ Portland, Oregon 97201, U.S.A.
}

\begin{abstract}
Summary. A variation of the dye dilution technique was used to determine the volume of uterine fluid in 'implanting' and 'delayed implanting' mice. The method involves rinsing $\mathrm{Krebs}-\mathrm{R}$ inger-bicarbonate buffer containing [methyl $-{ }^{14} \mathrm{C}$ ] methylated-BSA through the uterine lumen and using the resulting decrease in concentration of the BSA to calculate the volume of uterine fluid. The results indicated that the volume of uterine fluid was essentially the same in 'implanting' and 'delayed implanting' mice (i.e. $300-400 \mathrm{nl} /$ pair of uterine horns). The total amounts of a substance recovered by rinsing the uteri would therefore provide an estimate of relative concentrations in situ.
\end{abstract}

\section{Introduction}

It has been suggested that humoral factors in uterine fluid are involved in regulation of the metabolic activity of blastocysts (Daniel \& Krishnan, 1969; Mintz, 1970, 1972; McLaren, 1973; Aitken, 1977b; Enders \& Given, 1977; Surani, 1977). In attempts to test this hypothesis, several investigators have compared the amounts of various substances in fluid rinsed from the uteri of 'delayed implanting' animals (i.e. those in which the embryos are metabolically dormant) and 'implanting' animals (i.e. those in which the embryos are metabolically active). For example, it has been shown in mice (Aitken, 1977a) and rats (Surani, 1975, 1976) that the total amount of protein in uterine fluid during delayed implantation is small and that increases as the embryos are activated to implant. Similar observations have been made with enzymes that are present in uterine fluid, including endopeptidase in the rat (Joshi \& Rosenfeld, 1976; Rosenfeld \& Joshi, 1977) and protease (Pinsker, Sacco \& Mintz, 1974) as well as chymotrypsin-like amidase activity (Hoversland \& Weitlauf, 1978) in the mouse.

However, before such data can be used to support the hypothesis that a change in the amount of a particular substance in uterine fluid might influence embryonic metabolism, it must be shown that the change actually reflects a different concentration in situ; this cannot be done without an estimate of the original volume of uterine fluid. Therefore, the present experiments were undertaken to determine the volume of uterine fluid in 'delayed implanting' and 'implanting' mice.

\section{Materials and Methods}

Virgin female white Swiss mice (6-8 weeks old) were selected at random stages of the oestrous cycle and ovariectomized via a dorsolateral incision. They were allowed to recover for 10 days, divided into 3 groups, and treated with ovarian hormones according to the following schedules: 
Group 1 mice received progesterone alone (2.0 mg/day s.c.) on Days $11-14$ (i.e. conditions for delayed implantation); Group 2 mice received progesterone alone on Days 11-12 followed by a combination of oestradiol-17 $\beta$ (25 ng) and progesterone on Days 13-14 (i.e. conditions for implantation; Weitlauf \& Greenwald, 1968); Group 3 mice received $0.1 \mathrm{ml}$ sesame seed oil s.c. on Days 11-12 followed by oestradiol-17 $\beta$ alone on Days 13-14. Animals were killed by cervical dislocation at the times indicated in Table 1. Their uteri were removed, trimmed free of mesenteries and fat, each horn was separated from the cervix.

The volume of fluid in each pair of uterine horns was estimated by the dilution of [methyl ${ }^{14} \mathrm{C}$ ]methylated-BSA $(20.0 \mu \mathrm{Ci} / \mathrm{mg}$ BSA; New England Nuclear, Boston, Massachusetts) in a Krebs-Ringer-bicarbonate buffer that was rinsed through the uteri. The volume of fluid in each pair of uterine horns $\left(V_{\mathrm{u}}\right)$ was calculated from the formula: $V_{\mathrm{u}}=$ $\left(V_{1} C_{1}-\left(V_{1} C_{\mathrm{e}}+B\right)\right) / C_{\mathrm{e}}$, where $V_{\mathrm{f}}$ is the original volume of buffer instilled into the uterine lumen; $C_{\mathrm{i}}$ is the concentration of $\left[\right.$ methyl $\left.{ }^{14} \mathrm{C}\right]$ methylated-BSA in the original buffer solution; $C_{\mathrm{e}}$ is the concentration of $\left[\right.$ methyl $\left.-{ }^{14} \mathrm{C}\right]$ methylated-BSA in the buffer solution after dilution by uterine fluid (i.e. effluent from the uterus); and $B$ is the amount of $\left[\right.$ methyl $\left.{ }^{14} \mathrm{C}\right]$ methylated-BSA 'bound' to the uterine horns.

Buffered isotope solution was prepared by adding $\left[\right.$ methyl $\left[{ }^{14} \mathrm{C}\right]$ methylated-BSA $(1 \mathrm{mg} / \mathrm{ml})$ to Krebs-Ringer-bicarbonate buffer ( $\mathrm{pH} 7.4$ ) containing $1 \mathrm{mg}$ non-labelled BSA/ml (final sp. act. $1.0-1.2 \mu \mathrm{Ci} / \mathrm{mg} \mathrm{BSA}$ ). The solution was then divided into aliquots and stored at $-20^{\circ} \mathrm{C}$ until used. The concentration of the $\left[\right.$ methyl $\left.{ }^{14} \mathrm{C}\right]$ methylated-BSA $\left(C_{1}\right)$ in the buffer was confirmed before the rinse procedure by pipetting 4 or $5 \mu \mathrm{l}$ ( $\pm 1 \%$, Dade pipettes) of the buffer into a scintillation vial containing $0.5 \mathrm{ml}$ distilled water followed by $5 \mathrm{ml}$ toluene-based scintillation cocktail $(0.4 \%(\mathrm{w} / \mathrm{v})$ PPO, $0.004 \%(\mathrm{w} / \mathrm{v})$ POPOP and $25.0 \%(\mathrm{v} / \mathrm{v})$ Triton X-100); radioactivity was estimated with a scintillation counter (Beckman LS-230, 90\% efficiency). The intra-assay coefficient of variation for these determinations was $1.5 \%(n=4)$ and the inter-assay coefficient of variation was $3 \%(n=4)$.

Each uterine horn was flushed with 3-4 $\mu \mathrm{l}$ of the buffer followed by a $45 \mu \mathrm{l}$ bolus of air to purge the lumen. Buffer and air were injected into the lumen near the utero-tubal junction with a $50 \mu \mathrm{l}$ Hamilton syringe and 25-gauge needle. The effluent buffer solution, diluted by uterine fluid, was collected via a cannula (made from a blunt hypodermic needle) inserted into the cervical end of the uterine horn and held in place by a modified haemostat (notched to accommodate the cannula) and bibulous paper cushion: total time in utero was 5-6 sec. The effluents from both uterine horns of each animal were pooled, $4-5 \mu \mathrm{l}$ of the effluent were pipetted into a scintillation vial, and the amount of $\left[\right.$ methyl $\left.{ }^{14} \mathrm{C}\right]$ methylated-BSA $\mu$ effluent $\left(C_{\mathrm{e}}\right)$ was determined.

To estimate the amount of $\left[\right.$ methyl $\left.-{ }^{14} \mathrm{C}\right]$ methylated-BSA 'bound' to the uterus $(B), 400 \mu \mathrm{l}$ PBS $\left(0-4^{\circ} \mathrm{C}, \mathrm{pH} 7 \cdot 4\right.$, containing $1 \mathrm{mg}$ non-labelled $\left.\mathrm{BSA} / \mathrm{ml}\right)$ were first flushed through each horn to remove unbound residual $\left[\right.$ methyl $\left.{ }^{14} \mathrm{C}\right]$ methylated-BSA in the lumen. This fluid collected from both horns of one animal was placed in a scintillation vial and the amount of radioactivity determined. Each pair of uterine horns was then dissolved in $2 \mathrm{ml} \mathrm{NCS}$ ('tissue solubilizer', Amersham) and the amount of radioactivity 'bound' to the epithelium $(B)$ was determined.

For purposes of calculation, the volume of buffer rinsed through each uterus $\left(V_{1}\right)$ was assumed to be equal to the total radioactivity instilled into the uterine lumen (summation of the radioactivity of the $\left[\right.$ methyl $\left.-{ }^{14} \mathrm{C}\right]$ methylated-BSA in the effluent, the residual washings, and that 'bound' to the uterus) divided by the original concentration of $\left[\right.$ methyl $\left.-{ }^{14} \mathrm{C}\right]$ methylated-BSA in the buffer $\left(C_{1}\right)$.

Calculated volumes of uterine fluid were transformed to natural logarithms, analysed for heterogeneity of variance by Bartlett's test, then evaluated for significant differences with a 2-way analysis of variance (Sokal \& Rohlf, 1969) followed by Duncan's multiple range tests within collection times or treatments (Steel \& Torrie, 1960). A similar procedure was used to determine significant differences in the amount of BSA that was 'bound' to the uterine epithelium. 


\section{Results}

In preliminary experiments undertaken to confirm that small differences in the volume of diluent could be detected by measuring changes in the concentration of [methyl $\left.-{ }^{14} \mathrm{C}\right]$ methylated-BSA a standard curve was made by pipetting $0.5,1 \cdot 0,2 \cdot 5,5 \cdot 0,10 \cdot 0$ and $15.0 \mu l$ diluent into $50 \mu \mathrm{l}$ aliquots of buffer containing $\left[\right.$ methyl $\left.{ }^{14} \mathrm{C}\right]$ methylated-BSA. The concentration of $[$ methyl${ }^{14} \mathrm{C}$ ]methylated-BSA was then determined by measuring the radioactivity in $5 \mu$ aliquots of each dilution. It was found that $1.0 \mu \mathrm{l}$ diluent resulted in a significant decrease in the concentration of [methyl ${ }^{14} \mathrm{C}$ ] methylated-BSA $(P<0.05)$, whereas $0.5 \mu \mathrm{l}$ did not $(P>0.05)$. A change in the concentration of BSA of $<1.9 \%$ therefore represented the lower limit of sensitivity for the assay.

Table 1. The volume (nl) of uterine fluid in the 2 uterine horns of each animal in 'delayed implanting' and 'implanting' mice

\begin{tabular}{lcccc}
\hline & & \multicolumn{2}{c}{ Day 4} & \\
\cline { 3 - 4 } Group* & $(12: 00 \mathrm{~h})$ & $06: 00 \mathrm{~h}$ & $12: 00 \mathrm{~h}$ & \\
\hline 1 (progesterone only) & $277 \pm 30^{\mathrm{a}}$ & $360 \pm 45^{\mathrm{a}}$ & $369 \pm 74^{\mathrm{a}}$ & $285 \pm 29$ \\
& $(12)$ & $(12)$ & $(5)$ & $(8) \mathrm{h})$ \\
\hline (progesterone + oestradiol) & $301 \pm 40^{\mathrm{a}}$ & $335 \pm 45^{\mathrm{a}}$ & $307 \pm 30^{\mathrm{a}}$ & $246 \pm 30$ \\
3 (oil control) & $(12)$ & $(11)$ & $(7)$ & $(11)$ \\
& $360 \pm 28^{\mathrm{a}}$ & $652 \pm 106^{\mathrm{b}}$ & $1513 \pm 252^{\mathrm{c}}$ & $3735 \pm 1077$ \\
& $(13)$ & $(12)$ & $(7)$ & $(14)$ \\
\hline
\end{tabular}

* Hormones were injected s.c. in $0 \cdot 1 \mathrm{ml}$ sesame seed oil daily at $12: 00 \mathrm{~h}$ (see text for details).

Values are mean \pm s.e.m. with the no. in parentheses indicating the no. of replicates, i.e. animals. Within rows, values with different superscript letters are significantly different $(P<0.05)$. Data collected at 12:00 h on Day 5 were not included in the statistical analysis (see text).

Table 2. The amount (ng) of albumin 'bound' to the uteri (i.e. 2 horns/animal) of 'delayed implanting' and 'implanting' mice

\begin{tabular}{lcccc}
\hline & \multicolumn{2}{c}{ Day 4} & \\
\cline { 3 - 4 } \multicolumn{1}{c}{ Group* } & $\begin{array}{c}\text { Day } 3 \\
(12: 00 \mathrm{~h})\end{array}$ & $06: 00 \mathrm{~h}$ & $12: 00 \mathrm{~h}$ & $\begin{array}{c}\text { Day 5 } \\
(12: 00 \mathrm{~h})\end{array}$ \\
\hline 1 (progesterone only) & $59 \pm 8^{\mathrm{ab}}$ & $58 \pm 11^{\mathrm{a}}$ & $72 \pm 12^{\mathrm{ab}}$ & $93 \pm 16^{\mathrm{b}}$ \\
2 (progesterone + oestradiol) & $(12)$ & $(12)$ & $(5)$ & $(8)$ \\
3 (oil control) & $49 \pm 10^{\mathrm{a}}$ & $115 \pm 21^{\mathrm{b}}$ & $108 \pm 23^{\mathrm{b}}$ & $110 \pm 16^{\mathrm{b}}$ \\
& $(12)$ & $(11)$ & $(7)$ & $(11)$ \\
& $27 \pm 3^{\mathrm{a}}$ & $44 \pm 8^{\mathrm{ab}}$ & $46 \pm 3^{\mathrm{b}}$ & $46 \pm 5^{\mathrm{b}}$ \\
\hline
\end{tabular}

\footnotetext{
* Hormones were injected s.c. in $0.1 \mathrm{ml}$ sesame seed oil daily at $12: 00 \mathrm{~h}$ (see text for details).

Values are mean \pm s.e.m. with the no. in parentheses indicating the no. of replicates, i.e. no. of animals. Within rows, values with different superscript letters are significantly different $(P<0.05)$.
}

The volume of uterine fluid in 'delayed implanting' mice was unchanged during the 3 days of treatment (Table 1, Group 1) and was unchanged as the dormant phase of 'delayed implantation' was terminated by the injection of oestradiol-17 $\beta$ (Table 1, Group 2). The volumes of uterine fluid in 'delayed implanting' and 'implanting' animals were not significantly different. In contrast, the volume of uterine fluid was significantly increased in animals injected with oestradiol-17 $\beta$ alone (Table 1, Group 3,06:00 h on Day 4). A second injection of oestradiol-17 $\beta$ caused a further increase in the volume of uterine fluid (Table 1, Group 3, 12:00 h on Day 4 to 12:00 h on Day .5). Data collected at 12:00 h on Day 5 are shown in Table 1 but were not included in the statistical analysis due to heterogeneity that could not be corrected by transformation to lns. 
The amount of $\left[\right.$ methyl $\left.{ }^{14} \mathrm{C}\right]$ methylated-BSA that was 'bound' to the uterus increased with time in all three treatment groups (Table 2): the increase was greater in Group 2 than in Group 3 $(P<0.05)$ and similar in Groups 1 and 2.

Histological examination of uteri from each treatment group indicated that the epithelium was intact after the rinsing procedure.

\section{Discussion}

Results of the present experiments demonstrate that oestradiol-17 $\beta$, given alone, leads to an increase in the volume of fluid in the uteri of ovariectomized mice. However, it does not have that effect when given in conjunction with progesterone and the volume of uterine fluid does not appear to be significantly changed as the dormant phase of 'delayed implantation' is terminated.

The assay used here was a variation of that devised by Kulangara (1972). As modified, it was sensitive to changes in the concentration of $\left[\right.$ methy $\left.l{ }^{14} \mathrm{C}\right]$ methylated-BSA of $1.9 \%$ or less, i.e. approximately $150 \mathrm{nl}$ uterine fluid when $8 \mu \mathrm{l}$ buffer were used, and was very reproducible. Two potential sources of error in this procedure are 'binding' of [methyl $\left.-{ }^{14} \mathrm{C}\right]$ methylated-BSA to the uterus and disruption of the uterine epithelium which could allow tissue fluids into the lumen; either would lead to overestimates of the volume of uterine fluid (e.g. $100 \mathrm{ng}$ [methyl${ }^{14} \mathrm{C}$ lmethylated-BSA 'bound' would lead to an overestimate in the volume of $125 \mathrm{nl}$ ). The amount of $\left[\right.$ methyl- $\left.{ }^{14} \mathrm{C}\right]$ methylated-BSA that was 'bound' increased in each of the three treatment groups but there was significantly less 'binding' after treatment with oestradiol-17 $\beta$ alone than with the combination of progesterone and oestradiol-17 13 or progesterone alone. From the present experiments, it could not be determined whether the increases in 'binding' were due to incorporation of tracer into pinopods (Enders \& Nelson, 1973; Parr \& Parr, 1977), changes in the morphology of the luminal surface (Nilsson, 1966b; Smith \& Wilson, 1974), changes in the molecular structure of the epithelial cell surface (Hewitt, Beer \& Grinnell, 1979), or a combination of these hormone-dependent changes. However, to correct for this potential source of error, the amount of $\left[\right.$ methyl $\left.{ }^{14} \mathrm{C}\right]$ methylated-BSA 'bound' to each pair of horns was accounted for in the calculations. In fact, the actual amounts of tracer lost in this way were small and even if the procedure had been omitted the conclusions would not be altered. The possibility that 'gross' disruptions of the epithelium occurred during the flushing procedure was ruled out, at least at the light microscopic level, by histological examinations.

The findings, that oestradiol- $17 \beta$ alone increased the volume of uterine fluid but that it did not do so when given in conjunction with progesterone, are in agreement with those reported by Armstrong (1968) for prepubertal rats. However, it is known that in mice the opposing surfaces of uterine epithelium come into close apposition under the influence of progesterone and that this 'closure' is even more marked when oestradiol-17 $\beta$ is added (Nilsson, 1966a). It might therefore have been anticipated that the volume of uterine fluid would be further reduced when 'delayed implantation' was terminated. The present results provide no explanation for this apparent discrepancy but it seems probable that the increases in the overall dimensions of the uterus which occur with these treatments may compensate for the effects of 'closure'.

Numerous studies have been reported in which the contents of uteri have been flushed out and analysed for the total content of various substances (see 'Introduction' for references). When differences have been found it has usually been assumed that development of an embryo in the lumen could be influenced by such changes. The observation by Kulangara (1972) that the total protein content in fluid flushed from lactating and non-pregnant rabbits was the same while the fluid volumes and hence the concentrations of protein in utero were different indicates a potential hazard in that assumption. On the other hand, the present results demonstrate that in the experimentally produced 'delay of implantation' in ovariectomized mice (i.e. at least by the treatment scheme used here), the volumes of uterine fluid are not different as the dormant phase 
is terminated. Therefore, the increase in the total amount of chymotrypsin-like amidase that was observed in uterine fluid as dormant mouse embryos were activated for implantation (Hoversland \& Weitlauf, 1978) appears to reflect an actual increase in the concentration of the enzyme. It seems possible that this change is involved with the activation of the embryo or some other aspect of the implantation process.

This work was submitted to the Graduate Council, University of Oregon Health Sciences Center by R.C.H. as partial fulfilment of the requirements for the Ph.D. degree and was supported by NICHD Grants HD 07133 and HD 00020, and PHS Grant HD 08496.

\section{References}

Aitken, R.J. (1977a) Changes in the protein content of mouse uterine flushings during normal pregnancy and delayed implantation, and after ovariectomy and oestradiol administration. J. Reprod. Fert. 50, 29-36.

Aitken, R.J. (1977b) Embryonic Diapause. In Development in Mammals, Vol. 1, pp. 307-359. Ed. M. H. Johnson. North-Holland, Amsterdam.

Armstrong, D.T. (1968) Hormonal control of uterine lumen fluid retention in the rat. Am. J. Physiol. 214, 764-771.

Daniel, J.C., Jr \& Krishnan, R.S. (1969) Studies on the relationship between uterine fluid components and the diapausing state of blastocysts from mammals having delayed implantation. J. exp. Zool. 172, 267-282.

Enders, A.C. \& Given, R.L. (1977) The endometrium of delayed and early implantation. In Biology of Uterus, pp. 203-243. Ed. R. M. Wynn. Plenum Press, New York.

Enders, A.C. \& Nelson, D.M. (1973) Pinocytotic activity of the uterus of the rat. Am.J. Anat. 138, 277-300.

Hewitt, K., Beer, A.E. \& Grinnell, F. (1979) Disappearance of anionic sites from the surface of the rat endometrial epithelium at the time of blastocyst implantation. Biol. Reprod. 21, 691-707.

Hoversland, R.C. \& Weitlauf, H.M. (1978) The effect of estrogen and progesterone on the level of amidase activity in fluid flushed from the uteri of ovariectomized mice. Biol. Reprod. 19, 908-912.

Joshi, M.S. \& Rosenfeld, M.G. (1976) Hormonal influence on the appearance of uterine specific peptidase in the rat and mouse. In Protides of the Biological Fluids, Vol. 24, pp. 109-112. Ed. H. Peeters. Pergamon, Oxford.

Kulangara, A.C. (1972) Volume and protein concentration of rabbit uterine fluid. J. Reprod. Fert. 28, 419-425.

McLaren, A. (1973) Blastocyst Activation. In The Regulation of Mammalian Reproduction, pp. 321330. Eds S. J. Segal, R. Crozier, P. A. Corfman \& P. G. Conliffe. Thomas, Springfield.

Mintz, B. (1970) Control of embryo implantation and survival. Adv. Biosci. 6, 317-342.
Mintz, B. (1972) Implantation-initiating factor from mouse uterus. In Biology of Fertilization and Implantation, pp. 343-356. Eds K. S. Moghissi \& E. S. E. Hafez. Thomas, Springfield.

Nilsson, O. (1966a) Estrogen-induced increase of adhesiveness in uterine epithelium of mouse and rat. Expl Cell Res. 43, 239-241.

Nilsson, O. (1966b) Structural differentiation of luminal membrane in rat uterus during normal and experimental implantation. Z. Anat. EntwGesch. 125, 152-159.

Parr, M.B. \& Parr, E.L. (1977) Endocytosis in the uterine epithelium of the mouse. J. Reprod. Fert. 50, 151-153.

Pinsker, M.C., Sacco, A.G. \& Mintz, B. (1974) Implantation-associated proteinase in mouse uterine fluid. Devl Biol. 38, 285-290.

Rosenfeld, M.G. \& Joshi, M.S. (1977) A possible role of a specific uterine fluid peptidase in implantation in the rat. J. Reprod. Fert. 51, 137-139.

Smith, A.F. \& Wilson, I.B. (1974) Cell interaction at the maternal-embryonic interface during implantation in the mouse. Cell Tiss. Res. 152, 525-542.

Sokal, R.R. \& Rohlf, F.J. (1969) Biometry. W. H. Freeman and Company, San Francisco.

Steel, R.G.D. \& Torrie, J.E. (1960) Principles and Procedures in Statistics. McGraw-Hill, New York.

Surani, M.A.H. (1975) Hormonal regulation of proteins in the uterine secretions of ovariectomized rats and the implications for implantation and embryonic diapause. J. Reprod. Fert. 43, 411-417.

Surani, M.A.H. (1976) Uterine luminal proteins at the time of implantation and embryonic diapause. $J$. Reprod. Fert. 48, 141-148.

Surani, M.A.H. (1977) Cellular and molecular approaches to blastocyst uterine interactions at implantation. In Development in Mammals, Vol. 1, pp. 245-305. Ed. M. H. Johnson. North-Holland, Amsterdam.

Weitlauf, H.M. \& Greenwald, G.S. (1968) Influence of estrogen and progesterone on the incorporation of ${ }^{35} \mathrm{~S}$ methionine by blastocysts in ovariectomized mice. J. exp. Zool. 169, 463-470. 